\title{
PINGUiCUla PRIMULIFLORA 'ROSE'
}

BOB ZIEMER • McKinleyville • California $・ U S A \cdot b o b @$ carnivorousplants.org

Pinguicula primuliflora (Wood \& Godfr.) is native to the Gulf Coastal Plain of southeastern United States. The pale purple flowers are solitary, spurred, 2-lobed, and trumpet-shaped (Fig 1a). This warm-temperate perennial butterwort is one of the carnivorous plants that is propagated for mass markets and can be found in most garden centers. It is easily grown by beginners and readily propagates by plantlets that form on the leaf margins.

Pinguicula primuliflora 'Rose' (Ban) is a variant or possibly hybrid that produces a beautiful double flower (Fig. 1 and Back Cover). Other than the unique flower, the plant looks identical to the typical P. primuliflora.

As described in the accompanying translation by Koji Kondo of an article that appeared in the October 2000 issue of The Journal of Insectivorous Plant Society, P. primuliflora 'Rose' was discovered in May 1995 by Mitsuaki Ban growing among his P. primuliflora plants.

The name 'Rose' suggests that the flower resembles that of a rose (Rosa spp.). The name was coined by Mr. Ban and has been in common use for many years. This magnificent cultivar has become widely distributed and is now grown throughout the world.

The double flower is infertile. Propagation must be by vegetative methods. Plantlets are easily and naturally produced by budding at the leaf margins.

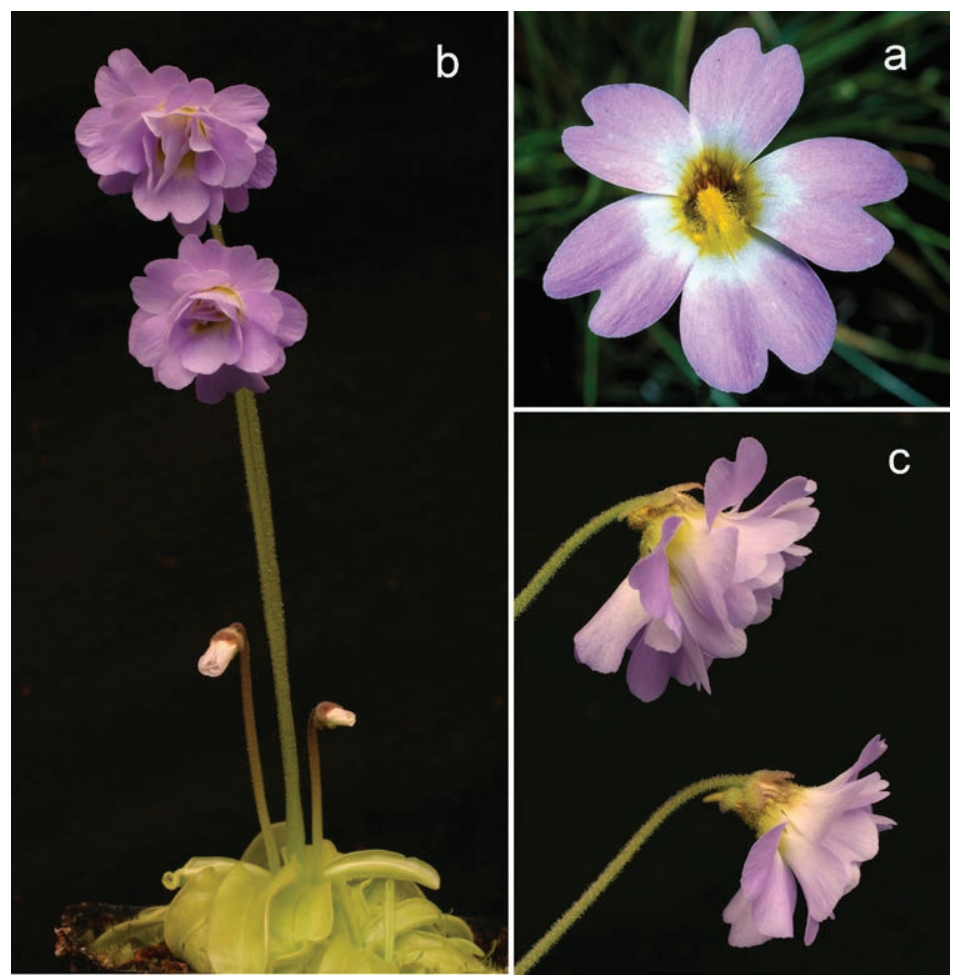

Figure 1: Comparison of (a) Pinguicula primuliflora flower with (b, c) Pinguicula primuliflora 'Rose'. Photo (a) by Barry Rice; (b and c) by Bob Ziemer. 


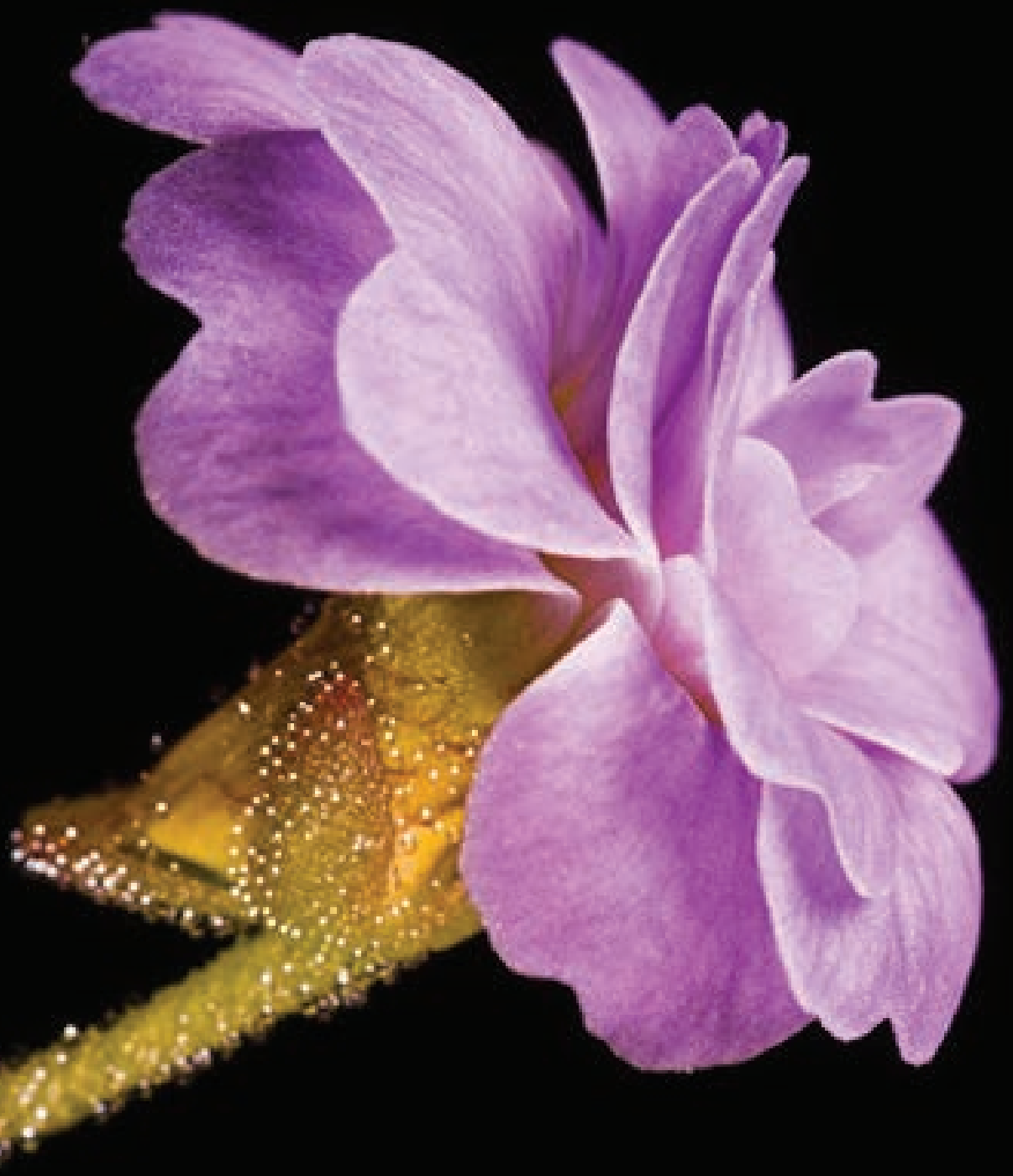




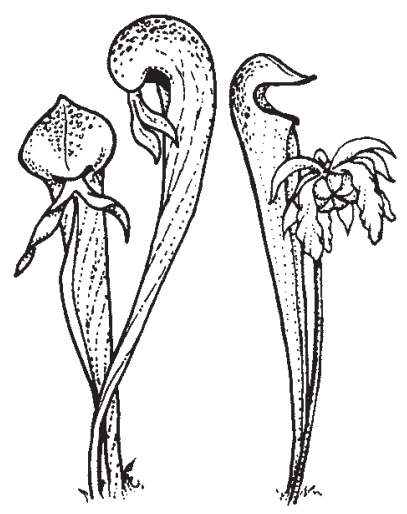

\section{CARNIVOROUS \\ PLANT \\ NEWSLETTER}

Journal of the International

Carnivorous Plant Society

www.carnivorousplants.org

Volume 43, Number 3 September 2014

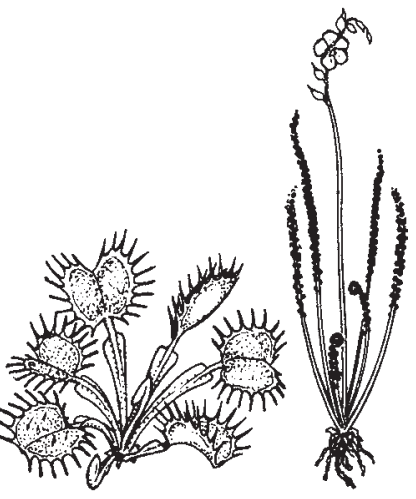

\section{Front Cover: Cephalotus follicularis growing near the Donnelly River, Western Austra- lia. Photo by Richard Nunn. Article on page 96.}

\section{Back Cover: Pinguicula primuliflora 'Rose'. Photo by Barry Rice. Article on page 103.}

Carnivorous Plant Newsletter is dedicated to spreading knowledge and news related to carnivorous plants. Reader contributions are essential for this mission to be successful. Do not hesitate to contact the editors with information about your plants, conservation projects, field trips, or noteworthy events. Advertisers should contact the editors. Views expressed in this publication are those of the authors, not the editorial staff.

All correspondence regarding dues, address changes and missing issues should be sent to the Membership Coordinator at the ICPS. Do not send such correspondence to the editors. Checks for subscriptions should be made to the ICPS in US funds. Dues for 2014 are \$35 for the first year of membership; renewals are \$30 per year.
International Carnivorous Plant Society, Inc.
2121 N. California Blvd., Suite 290
Walnut Creek, CA 94596-7351, USA
icps@carnivorousplants.org

President

Secretary/Treasurer

Board Member

Board Member

Board Member

Board Member

Administrator

Seed Bank Manager

CPN Editors

Managing Editor

Editor

Editor

Science Editor

Science Editor \& Cultivar Registrar

\author{
Marcel van den Broek, marcel@carnivorousplants.org \\ Richard Myers, richard@carnivorousplants.org \\ Greg Bourke, Conservation Director, greg@carnivorousplants.org \\ Richard Nunn, richardnunn@carnivorousplants.org \\ Jan Schlauer, jan@carnivorousplants.org \\ Bob Ziemer, bob@carnivorousplants.org \\ Cindy Slezak, cindy@carnivorousplants.org \\ John Brittnacher, john@carnivorousplants.org \\ editor@carnivorousplants.org \\ Bob Ziemer \\ Barry Rice \\ Djoni Crawford \\ Fernando Rivadavia \\ Jan Schlauer
}

Date of effective publication of the June 2014 issue of Carnivorous Plant Newsletter: 2 June 2014.

The ICPS is the International Cultivar Registration Authority (ICRA) for the names of cultivated carnivorous plants according to the International Code of Nomenclature for Cultivated Plants. Send relevant correspondence to the ICPS, Inc.

Carnivorous Plant Newsletter is published quarterly in March, June, September, and December by the ICPS, Inc., 2121 N. California Blvd., Suite 290, Walnut Creek, CA 94596, USA. Periodicals postage paid at Richmond, CA and additional mailing offices. Postmaster: Send address changes to ICPS, Inc., 2121 N. California Blvd., Suite 290, Walnut Creek, CA 94596, USA. Printed by Allen Press, Inc., 810 E. 10th Street, Lawrence, KS 66044. Logo and masthead art: Paul Milauskas. (C) 2014 Carnivorous Plant Newsletter. All rights reserved. ISSN \#0190-9215 